\title{
Chemical imaging of microstructure of chickpea seed tissue within a cellular dimension using synchrotron infrared microspectroscopy: A preliminary study
}

\author{
Xin Feng ( $\nabla$ 3haofx@gmail.com ) \\ Virginia Tech https://orcid.org/0000-0002-3986-3714 \\ $\mathrm{Na}$ Liu \\ Canadian Light Source Inc \\ Peiqiang $\mathrm{Yu}$ \\ University of Saskatchewan
}

\section{Research}

Keywords: chickpea, microstructure, synchrotron, infrared microspectroscopy, chemical imaging

Posted Date: July 17 th, 2020

DOl: https://doi.org/10.21203/rs.3.rs-40837/v2

License: (c) (i) This work is licensed under a Creative Commons Attribution 4.0 International License. Read Full License

Version of Record: A version of this preprint was published at Journal of Agricultural and Food Chemistry on September 18th, 2020. See the published version at https://doi.org/10.1021/acs.jafc.0c04446. 
The authors have withdrawn this preprint from Research Square 